IZA DP No. 5927

Climate Change, Natural Disasters and Migration: An Empirical Analysis in Developing Countries

Alassane Drabo

Linguère Mously Mbaye

August 2011 


\title{
Climate Change, Natural Disasters and Migration: An Empirical Analysis in Developing Countries
}

\author{
Alassane Drabo \\ CERDI, Université d'Auvergne \\ Linguère Mously Mbaye \\ CERDI, Université d'Auvergne \\ and IZA \\ Discussion Paper No. 5927 \\ August 2011 \\ IZA \\ P.O. Box 7240 \\ 53072 Bonn \\ Germany \\ Phone: +49-228-3894-0 \\ Fax: +49-228-3894-180 \\ E-mail: iza@iza.org
}

\begin{abstract}
Any opinions expressed here are those of the author(s) and not those of IZA. Research published in this series may include views on policy, but the institute itself takes no institutional policy positions.

The Institute for the Study of Labor (IZA) in Bonn is a local and virtual international research center and a place of communication between science, politics and business. IZA is an independent nonprofit organization supported by Deutsche Post Foundation. The center is associated with the University of Bonn and offers a stimulating research environment through its international network, workshops and conferences, data service, project support, research visits and doctoral program. IZA engages in (i) original and internationally competitive research in all fields of labor economics, (ii) development of policy concepts, and (iii) dissemination of research results and concepts to the interested public.
\end{abstract}

IZA Discussion Papers often represent preliminary work and are circulated to encourage discussion. Citation of such a paper should account for its provisional character. A revised version may be available directly from the author. 


\section{ABSTRACT}

\section{Climate Change, Natural Disasters and Migration: An Empirical Analysis in Developing Countries}

The aim of this paper is to assess the relationship between natural disasters caused by climate change and migration by examining migration rates and levels of education in developing countries. Many studies such as the Stern review (2007) or the Intergovernmental Panel on Climate Change (IPCC, 2007) predict an intensification of climate change for future years. Thus climate change has taken an essential place in world governance. The relationship between climate change, natural disasters and migration is crucial; developed countries need to manage the increasingly complicated issues of additional incoming migratory flows caused by environmental degradation. We investigate this relationship by using panel data from developing countries in order to see the effect of natural disasters on migration rates and how that varies according to the level of education. Estimations are made with a country fixed effects estimator through an accurate econometric model. The results confirm previous studies, namely that natural disasters are positively associated with emigration rates. But beyond this result, the main contribution of this paper is to show that natural disasters due to climate change exacerbate the brain drain in developing countries characterized by the migration of highly skilled people just when those countries are at their most vulnerable and need greater support from skilled workers to deal with the damage associated with natural disasters. The paper also shows that this effect varies depending on geographical location.

JEL Classification: O15, Q54

Keywords: climate change, natural disasters, migration

Corresponding author:

Linguère Mously Mbaye

CERDI - CNRS

Université d'Auvergne

65 Bd François Mitterrand

63000 Clermont-Ferrand

France

E-mail: linguere.m_baye@u-clermont1.fr 


\section{Introduction}

International migration is of great concern to developing countries. The movement of human capital is led by economic, demographic, political, social, cultural and environmental factors in both the sending country (push factors) as well as in destination countries (pull factors). The main reason for international migration found in the theoretical and the empirical literature is differences in economic opportunities or, more precisely, wages differential (Harris and Todaro, 1970; Ghatak et al. 1996). Beyond the wages differential, migration is considered as a way to diversify income sources (Stark, 1991), to deal with bad political institutions, large social disparities, conflicts, and the lack of good infrastructure. People also migrate for family reunification or to join relatives abroad. Finally, because of globalization, there is a decreasing of the uncertainty caused by modern communication technologies such as the internet and satellite $\mathrm{TV}$, which might be an explanation for persistently rising migration in recent decades. In a word, migration is a possibility for people to improve their quality of life and all the factors previously named can be affected directly or indirectly by climate change and natural disasters.

History demonstrates that climate change is often associated with massive movements of population and that the natural environment is probably the oldest determinant of migration and population displacement. Many studies such as the Stern report (2007) and the Intergovernmental Panel on Climate Change (IPCC, 2007) predict an intensification of climate change for the forthcoming years. According to the International Organization for Migration (IOM), by the half century, 200 million people (equal to the current estimate of international migrants) could be permanent or temporary environmental migrants ${ }^{2}$ within their countries or overseas. Climate change has, thus, taken an important place in world governance. But the partial failure of the Copenhagen Conference (2009) shows that it is difficult for the states to agree on the strategy to adopt in order to reduce their impact on the environment. The interests and the means of action are different according to each nation's level of development. Indeed, developed countries are responsible for an important part $^{3}$ of pollution and greenhouse gas emission compared to developing countries, which bear the brunt of this environmental degradation and are disproportionately affected because of their

\footnotetext{
${ }^{2}$ We consider the term "environmental migrants", because it is larger and inclusive than environmental refugees. It takes into account the forced population displacement due to environmental reasons; with push factors largely more determinant then pull factors (see Appendix 1 for other definitions).

${ }^{3}$ Rich countries will be responsible for $60-80 \%$ of gas emission by 2050 (Stern, 2007)
} 
economic vulnerability and their lack of means due to poverty. This environmental decline can induce natural disasters among other problems and, for the population of those countries, migration is one of the solutions to confront this issue. The management of supplementary migratory flows due to environmental degradation are made more complicated for developed countries by issues of migration from developing countries. Environmental migration is often at the origin of population displacement which can affect the stability of the hosting areas in many ways. It can induce conflicts with local populations by putting pressure on employment and local wages, trade and natural resources such as water, especially if those regions are already poor.

Since the second half of the eighties, many studies have been conducted on the effect of climate change on involuntary population displacement. In recent decades, Reuveny (2007) argues that the effects of climate change on migration can be predicted by exploring the effects of environmental problems on migration. People can adapt to these problems by either staying in place and doing nothing, staying in place and mitigating the problems, or by leaving the affected areas, depending on the extent of problems and the mitigation capabilities. According to Smith (2007) migration on a permanent or temporary basis has always been one of the most important survival strategies adopted by people confronted by natural or human-caused disasters. Naudé (2008) shows in the Sub-Saharan Africa context that environmental pressure has an impact on migration through the frequency of natural disasters. Poston et al (2009) show the effect of climate change on in-migration, outmigration and net migration among 50 states of the United States of America and their results are confirmed by Reuveny and Moore (2009) who demonstrate that environmental decline plays a statistically significant role in out-migration, pushing people to leave their homes and move to other countries. Finally, Marchiori and Schumacher (2011) found that minor impacts of climate change have major impacts on the numbers of migrants.

Relative to this literature, the main contribution and the aim of this paper is to examine the relationship between climate change and migration by studying the effect on migration rates of natural disasters caused by climate change but above all, and different from previous studies, by examining the effect of natural disasters on migration in the context of the level of people's education.

The paper then investigates the relationship between climate change, migration and natural disasters by using panel data from developing countries. Estimationss are made with a 
country fixed effects estimator through an accurate econometric model and the results confirm previous studies, namely that natural disasters are positively associated with emigration rates. But, beyond this, the paper shows that natural disasters due to climate change exacerbate the brain drain in developing countries by involving the migration of highly skilled people, and this effect varies depending on the geographical location of the countries.

The next section presents a literature review on the climate change issue in developing countries and the relationship between climate change, natural disasters and migration. In Section 3 we present the empirical design while the estimations results and robustness checks are discussed in Section 4. Concluding remarks and implications are provided in the last section.

\section{Literature Review}

The forecasts concerning environmental issues due to climate change are alarming. According to Dyson (2005), there will inevitably be a major rise in atmospheric $\mathrm{CO}^{2}$ during the 21 st century due among other causes to the momentum in economic and demographic processes. Stern (2007) warns that, by 2035, a rise in temperature of over $2^{\circ} \mathrm{C}$ induced by a rapid increase of greenhouse gas emissions could be doubled compared with its pre-industrial level ${ }^{4}$. In the long term, the temperature rise may exceed $5^{\circ} \mathrm{C}$, which is equivalent to the change in average temperatures from the last ice age to today. Marine eco-systems and food stocks are threatened by oceanic acidification due to carbon dioxide levels. Due to global warming, the Arctic will be ice-free in summer by 2100 because of a reduction of sea ice, and 15 to $40 \%$ of its species may become extinct. Melting glaciers will result in a rise in sea levels, particularly in the subtropics (Meehl and al., 2006), putting pressure on coastal areas and small islands. It will also threaten 4 million $\mathrm{km}^{2}$ of land representing home to $5 \%$ of the world's population, and may increase flood risks during wet seasons and reduced water supplies to one sixth of the world's population. Global warming, by altering the environment, has a significant effect on human health and infectious diseases (Schrag and Wiener, 1995; Khasnis and Nettleman, 2005). It entails natural disasters which affect housing, infrastructure, crop yield and livestock and consequently weakens economies (Perch-Nielsen, et al., 2008).

\footnotetext{
${ }^{4}$ According to this report, average global temperatures could increase by $2-3^{\circ} \mathrm{C}$ within the next fifty years.
} 


\subsection{Climate change issue in developing countries}

Climate has a significant effect on well-being and levels of happiness. Rehdanz and Maddison (2005) show that temperature changes benefit high latitude countries whereas they negatively affect low latitude countries. Indeed, a small amount of global warming would increase the happiness of those living in Northern countries, whereas it is the reverse for people living in high temperature regions. According to Stern (2007), predictions for developing countries reveal alarming future agricultural output and a reduction in crop yields, food security and issues related to water. Climate change involves droughts which are responsible for an increase in food prices, disease, and consequently an increase in health expenditure. Moreover, populations have to deal with the issue of water, the most climate sensitive economic resource for these countries. In South Asia, for example, climate change will increase rainfall and flooding with a direct effect on agricultural production, and with serious consequences in a region with a high population growth. In Latin America and Caribbean areas, serious threats exist to the rainforests with direct consequences for the subsistence of populations depending on the Amazonian forest. In Sub-Saharan Africa, an increase in sea level threatens coastal cities when higher temperatures raise risks of malnutrition, starvation and malaria, decreased river flow and the subsequent availability of water. In the Nile Basin, the Middle East and North African countries, water stress and severe droughts could cause migration and violent conflicts ${ }^{5}$.

The poorest countries have also to cope with the economic consequences of climate change. Climate change weakens States and decreases their ability to provide opportunities and services to help people become less vulnerable, above all if those people already live in marginalized areas. Indeed, the economy of many developing countries is essentially based on agriculture and primary goods which are one of the main sectors directly touched by climate change and natural disasters. As well as their poverty, developing countries are in a disadvantageous situation due to their rapid population growth, their massive urbanization and their geographical environment, which make them more vulnerable and less able to adapt to climate change. It decreases GDP growth, increases the deficit and the external debt of countries often already weakened economically. Moreover, their low income levels and their underdeveloped financial markets make for unattainable insurances and credits to cover them

\footnotetext{
${ }^{5}$ In SSA, on 80 million people suffering of starvation due to environmental factors, 7 million migrated to obtain food (Myers, 2005). The increasing in temperature of $2^{\circ} \mathrm{C}$ involve an increasing in population affected by malaria in Africa of 40-80 million people (70-80 million people affected with an increasing of $3^{\circ} \mathrm{C}-4^{\circ} \mathrm{C}$ ). By 2020 , between 75 and 250 million of African people will be exposed to water stress caused by climate change (Stern, 2007).
} 
in case of climatic shocks, which increase their vulnerability at individual and national levels. Climate change is, then, a constraint to the achievement of the Millennium Development goals and to sustainable development in general (Stern, 2007). Many developing countries are experiencing an increase in the frequency and costs of natural disasters which are estimated on average at 5\% of their GDP between 1997 and 2001 (IMF, 2003). In India and South East Asia the reduction in GDP due to climate change is estimated at between 9 and $13 \%$ by 2100 compared with a situation without climate change. The cost of adaptation for these countries will be at least between $5 \%$ and $10 \%$ of GDP and will weigh on government budgets, all the more so since less than $1 \%$ of losses from natural disasters were insured in low-income countries from 1985 to 1999 . The frequency of climate events does not give time to rebuild or reconstitute their patrimony, keeping them in a poverty trap. There is a crowding-out effect because the poorest are obliged to reallocate their resources to deal with the consequences of climate change instead of investing in human capital expenditure such as children's education or other productive investments. Immediate and strong reactions are then necessary for these specific countries to limit the serious impact of climate change on them. They suffer a "double penalty" because, in the current context, less-developed countries may be trapped in a vicious circle: their poverty makes them more vulnerable in the face of climate change and due to their poverty, climate change will have serious consequences on health, income and growth prospects and will trigger their poverty and vulnerability. In spite of this situation described previously, climate change is unfortunately considered as a long-term problem and future impacts of climate change do not have priority. Concerning this point, Ikeme (2003) analyzes the low capacity adaptation of Sub-Saharan Africa (SSA) countries to cope with climate change effects. Indeed, low adaptive capacity increases vulnerability, social and economic costs which affect human capital and the development levels of these areas, which constitute transmission channels for migration. For these countries, adaptation does not appear to be urgent issue and is underestimated by these most vulnerable countries. Indeed, even if adaptation is globally recognized as a means to preventing and coping with the impacts of climate change, there is a relative indifference and insufficient measures in order to reinforce the capacity of adaptation. Indeed, they are often in a difficult context with problems such as poverty, institutional weakness, low levels of education and skills or an inexistence of welfare systems; they are then obliged to act in emergency in case of climate effects (Washington and al., 2006). Moreover, developing countries, particularly in SSA, consider the developed countries to be the major cause of climate change, and wish to let them take the responsibility to manage them. 


\subsection{How Climate change and natural disasters can affect migration?}

Migration is considered as a possible adaptive response to risks associated with climate change (Mcleman and Smit, 2006). Using Northern Ethiopia as an example, MezeHausken (2000) shows how climate change triggers migration in dryland areas of less developed countries. The impact of drought on migration depends on the intensity of the change, the vulnerability of the individual who suffers the change and the availability of survival strategies. The intensity of the climate change includes damage caused by the combination of natural, socio-economic, technological and perceived conditions. The vulnerability means an individual's risk of exposure to the severe consequences of climatic disaster and the incapacity to cope with its consequences. Survival strategies are actions taken to avert and to manage the climatic disaster after the event. At the beginning of a drought, not all people are equally vulnerable in the face of the climatic change. Families with more survival strategies manage to resist migration longer than those with fewer survival strategies. But there comes a time after which survival strategies are reduced for all members of society at which point all people are affected in similar ways and are obliged to migrate. Migration is a solution to the failure of different survival strategies. Nevertheless it is important to recognize that, in regions already with a high level of poverty and difficult living conditions, climatic change is a triggering factor of migration.

Notwithstanding this, views differ on whether migration could be considered as adaptation. Some characterize migration as a failure of, rather than as a form of, adaptation. Some operational organizations and academics point out the role that migration may play in helping home communities to adapt themselves, using the resources from migrant remittances (IOM, 2007; Barnett and Jones, 2002). Others express the view that migration is a maladaptive response because the migration may trigger an increased risk for those who move and also possibly for areas towards which migrants move (Oliver-Smith, 2009). Socially some factors including governance help determine whether people, threatened by rapid or slow onset environmental change, can remain in their homes or return once the threat has passed. For instance, in the aftermath of Hurricane Katrina, out of the 1.5 million people displaced, only one-third returned and governance played a large role in that instance, 
underlining the need to understand how social and ecological factors interact and shape human mobility in the face of global environmental change (Warner, 2009).

According to Naudé (2008), climate change affects and can intensify migration through three channels, namely scarcity of water and land, natural hazards, and conflicts over natural resources. Indeed, migration towards new areas is often one of the main factors of environmental conflicts (Baechler, 1999b; Swain, 1993; Swain, 1996). Climate change may cause tensions and conflicts in communities receiving migrants (Adger and Barnett, 2007). McGregor (1994), studying the link between environmental change, migration and food security, shows that the displacement of a population due to climate change can induce conflicts linked to the food security of the hosting areas. Food aid given to the refugees may destabilize food prices and the local production of the host economy, which in turn can cause malnutrition in refugee camps or weaken some regions already affected by food shortages.

In general, the main channel leading to conflict is the way that climate change affects the livelihood of host populations by exerting pressure on local wages, by increasing competition for job opportunities, resulting in ethnic tension, mistrust, and friction and by affecting available resources, for instance by reducing access to land or to natural capital in general through deforestation.

\subsection{Some stylized facts}

Many stylized facts illustrate the relationship between climate change, natural disasters and migration. In Chinese ancient history, between 3550 and $2200 \mathrm{BC}$, during China's Bronze Age, the settled Zhou tribes experienced conflicts with the nomadic Rong and Di tribes and were relocated five times. Historians attributed these migrations only to political and military reasons whereas the movement of populations was also caused by climate change. Those migrations were a means to protect agriculture by conserving resources in order to economize food production threatened by drought (Huang and $\mathrm{Su}, 2008$ ). The climatic factor also influenced Polynesian migrations between 300 and 1400 (Bridgman, 1983).

Similarly in Asia in 1975, as a method of increasing self-reliance and to provide food security to its population, India constructed the Farraka dam on the River Ganges permitting large-scale irrigation of state land. But this project, by over-exploiting the river and diverting most of the Ganges' dry-season water, and without consulting Bangladesh which shares the 
river, induced serious ecological and political consequences. The consequential environmental degradation affected the living conditions of Bangladeshis through the destabilization of their ecosystem, the destruction of their essential sources of livelihood such as agriculture, industrial production and fishing. The environmental destruction caused by the Indian dam firstly affected the rural ecosystem and then displaced the Bangladesh population towards urban areas. But the low absorption capacity of Bangladesh cities made migration to India the only viable alternative. Subsequently the environmentally-caused displacement of the Bangladeshi migrants constituted a burden for Indian society, putting pressure on the availability of food and the labor market. Since these migrants were Muslims yet the major proportion of the receiving country was Hindu, problems were intensified by ethnic and political issues. Tensions between migrants and natives of the host country resulted in regional conflict which then spread to other parts of India (Swain, 1996). In Mali in the 1970s and 1980s, drought caused the migration of Tuareg people towards other countries. When they returned to Mali they were marginalized by the competition between nomad and settled people, resulting in a rebellion in 1990 (Meier and Bond, 2007). The El Niño events between the 1970s and 1990s caused extended droughts in Ethiopia. They were followed by famine and political turmoil that resulted in radical changes of government, secession, and a massive program of population redistribution. The consequences of government-imposed migration policies, whose catalyst was climate change caused by repeated El Niño events, were certain changes in the ethnic composition and the geographic pattern of population growth of certain Ethiopian regions (Comenetz and Caviedes, 2002). Repeated droughts in the Senegal River basin triggered a conflict between Senegal and Mauritania which started when the river began to recede (Niasse, 2005). In 1996-1997 a severe drought induced a mass migration from Kenya to Somalia and Ethiopia. Because of a lack of adaptation and efficient measures, countries such as Madagascar, Zimbabwe and Kenya viewed their economies seriously affected respectively by droughts in 1992, floods in 1998, and cyclones in 2000. Nigeria, Senegal and Angola are all vulnerable to rises in sea level and flooding which affected thousands of people (Ikeme, 2003; Benson and Clay, 1998; Ngecu and Mathu, 1999). In 2004, the tsunami in Indonesia displaced 500,000 people whereas Hurricane Katrina in 2005 had serious consequences on human displacement with tens of thousands of migrants in 26 states of the USA. Hurricane Mitch, like Katrina, had a devastating effect on the most vulnerable people and increased male migration from Honduras to Nicaragua (Smith, 2007). 


\section{Empirical design}

The empirical framework is developed in this section and, before presenting the data, the three main specifications showing the different relationships between natural disasters and migration are discussed.

\subsection{Methodology}

Firstly, the effect of natural disasters caused by climate change on net migration rates is estimated using the following specification:

$$
\operatorname{mig}_{i, t}=\alpha_{1} \text { disaster }_{i, t}+\alpha_{k} X_{k, i, t}+\mu_{i}+\varepsilon_{i, t}
$$

Where $\operatorname{mig}_{\mathrm{i}, \mathrm{t}}$ and disaster $\mathrm{i}_{\mathrm{t}, \mathrm{t}}$ are respectively the migration and natural disaster variables for the country $i$ at the period $t ; X_{k, i, t}$ is the vector of control variables generally used in migration estimations; $\mu_{i}$ represents the countries' fixed effects and $\varepsilon_{i, t}$ the error term. The coefficient of natural disasters is expected to be positive.

Secondly, the analysis is specified by taking migration rates according to the education levels. We are interested in this point because we assume that natural disasters caused by climate change may affect the migration of people who are more educated or those who are more skilled. Often they are those who get a job and a salary so they have the means to go abroad, to be safe, and to provide an insurance for their family back in the affected country. With respect to policy implications, they can induce a brain drain whose effects will be more serious in this context where countries need large support for rebuilding and have a special need for skilled workers. We assume that this effect is higher for the most highly educated. So we have:

$$
\text { migeduc }_{i, t}^{j}=\alpha_{1}^{j} \text { disaster }_{i, t}+\alpha_{k}^{j} X_{k, i, t}+\mu_{i}+\varepsilon_{i, t}^{j}
$$

Where migeduc $_{j, i, t}$ is the migration rate associated with each educational level $\mathrm{j}(\mathrm{j}=$ low, medium and high educational levels).

The two objectives already discussed are estimated by using country OLS fixed effects estimator through an accurate econometric model. However, one may assume some endogeneity issues caused by measurement errors of the variable of interest or by a potential simultaneity bias between migration and natural disasters. But in our case we do not have 
these problems because we eliminate the measurement errors by using the CRED data which identifies the number of natural disasters each time such events arrive. Secondly, we assume that migration at the period $t$ cannot cause natural disasters at $t$ or before $t$, but only in the future. Since we estimate the effect of the number of natural disasters at the period $t$ on the migration rate at the same period, we do not have a double causality issue.

\subsection{Data}

The objective of this paper is to assess the effect of natural disasters caused by climate change on global migration rates and on migration rates according to the level of education. This relationship is investigated by using panel data with countries as unit observations. The dependent variables are the net migration rates between 1950 and 2010 made available by the United Nations Population Division and measured as the number of immigrants minus the number of emigrants over the period, divided by the person-years lived by the population of the receiving country over that period. It is expressed as the net number of migrants per 1,000 population. However, we choose to use the opposite of this measure (the difference between the total number of emigrants minus the number of immigrants divided by the person-years lived by the population of the receiving country over that period) to be in conformity with the other migration indicators with regard to their sign: indeed, a higher level of these variables indicates a higher level of migration.

We also use the Panel Data on International Migration of M. Schiff and M.C Sjöblom (2008) (World Bank Databases), which measures international migration from 1975 to 2000 of the six main destination countries: Australia, Canada, France, Germany, UK and USA. They measure emigration rates through the stocks of migrants from sending countries to these countries for three educational levels, namely low, medium and high, divided by the stock of adults $(+25)$ corresponding to the same educational level, in the country of origin plus the stock of migrants of sending countries. We prefer this database to that produced by Docquier and Marfouk (2006); the latter uses the same measure but for all OECD countries in 1990 and 2000, whereas the former has a larger temporal dimension and thus more observations.

For the climate change indicators representing the variables of interest, we use the Centre for Research on the Epidemiology of Disaster (CRED) data (2010) from 1900 to 2010. Firstly we use the total number of natural disasters in a country in a five year period. Secondly we are interested in: meteorological disasters using a variable which considers the number of events caused by storms; hydrological disasters using a variable which groups 
together the number of events caused by floods and other wet mass movements; and drought, wildfire and climatological disasters through a variable which measures the number of disasters caused by extremely high temperatures. We are interested in these three measures because they are the natural disasters which are mainly caused by climate change.

Other factors, such as the GDP per capita, the demographic pressure through variables such as young population and population density, the availability of arable land, the quality of the institutional situation in the country through political rights and civil war variables, can all influence migration and constitute the controls (see Table B.1 and Table B.2 in Appendix B for variables definition and sources, and summary statistics).

\section{Results}

\subsection{Natural disasters and net migration rates}

Estimations are made for poor and middle-to-lower income countries. Table 1 shows the results of the effect of natural disasters on net migration rates. Natural disasters are captured by four indicators expressed in logarithm: the total number of natural disasters (Column 1) and its desegregated components, namely meteorological, hydrological and climatological disasters (Column 2 to 4 ). The number of natural disasters has a significant positive impact on net migration rates confirming previously documented results (Naudé, 2008; Reuveny and Moore, 2009). This result is confirmed by the sub-components of natural disasters except for the climatological variable which becomes significant with one period lag (column 5). Moreover, if we introduce natural disasters and their disaggregated variables with one period lag (Table 2), it appears that all these variables are significant and positive. In a word, natural disasters have a contemporaneous and lagged effect except for climatological events. This is due to the fact that for storms, included in meteorological disasters, or floods and wet mass movements included in hydrological events, the mitigation and adaptation capabilities are less available for these types of events than for extreme temperatures events or droughts which are in the climatological category. Indeed, during short term hydrological events, people have less choice to stay, whereas climatological events permit them time to prepare their migration in the future. 


\subsection{The effect of the intensity of natural disasters on migration}

Even though the occurrence of natural disasters is a good measure, one could assume that the intensity is more relevant in assessing the relationship between climate change and migration. Thus, to check the robustness of the previous results, we make our estimations by using, for each sub-group of natural disasters (meteorological, hydrological and climatological variables), the costs representing total damages in US\$; the number of deaths and the number of people injured, made homeless and otherwise affected. Estimations in Table 3 confirm the previous results in Table 1 except for the number of deaths and the number of people affected by hydrological disasters which are not significant. Indeed, the contemporaneous effect of the intensity variables of natural disasters on net migration exists for meteorological events, but only the damage caused by hydrological events increase net migration rates.

\subsection{The effect of natural disasters on migration according to the education level}

The effect of natural disasters on migration according to the educational level is presented in Table 4. The dependent variables are emigration rates with respectively low, medium and high educational levels. The interest variable remains the number of natural disasters. Only those individuals with a high level of education migrate in the case of an increased incidence in the number of natural disasters. It means that natural disasters due to climate change heighten the brain drain phenomenon in developing countries just when they need the most skilled and qualified people to deal with the damage caused by natural disaster.

\subsection{Robustness check: the effect of natural disasters on highly educated migrants according to geographical location}

Even if natural disasters affect all countries, it is interesting to test if the behavior of highly educated people in the face of migration depends on the geographical location of the countries. The dependent variable is the migration of highly educated populations and the variables of interest are the number of natural disasters and some interaction terms between the number of natural disasters and geographical dummies ${ }^{6}$. We find in Table 5 some differences in migration behavior in Europe and Central Asia (ECA), Latin America and Caribbean (LAC), Middle East and North Africa (MENA) and South Asia (SA) regions. The effect is positive for ECA, LAC and SA regions, where we observe increased migration rates

\footnotetext{
${ }^{6} \mathrm{We}$ do not run the estimations for each sub-region dummy because of their low sample size.
} 
of highly skilled people caused by natural disasters. For ECA and LAC regions, the explanation may be that the receiving countries will be more tolerant in accepting them on account of their cultural and geographical proximity compared to other sending countries. For South Asia, the reason for this result may be due to the high frequency of natural disasters in this area and the low resilience of these countries. In these two cases, migrants will be integrated more easily in the job market of the receiving countries if they are qualified. Despite the geographical proximity with some receiving countries there is a negative relationship between the variable MENA and the migration variable. However, if we observe the coefficient of the variable numbers of natural disasters, it appears that the effect is almost equal to 0 . Therefore it is very unlikely that highly skilled people from the MENA region migrate because of natural disasters.

\section{Concluding Remarks and Implications}

Climate change is one of the main challenges of the twenty-first century for all countries in the world in general, and in particular for developing countries which are more sensitive to its effects. This paper assesses the relationship between natural disasters caused by climate change and migration by examining migration rates and levels of education. Results, from a fixed effects estimator, show that natural disasters have a significant and positive effect on net migration rates. But this effect is different according to the disaster type. Climatological disasters have only a positive lagged effect of one period on migration, unlike the other types of disaster which have a contemporaneous and lagged positive impact on migration. We also find that the effect is not the same for the different educational levels. Natural disasters have an effect only on the migration of people with a high level of education. Finally, we find some differences in migration behavior between highly educated people in European Central Asia, Latin America and Caribbean, Middle, East and North Africa and South Asia regions.

Natural disasters due to climate change raise equity issues for developing countries by heightening the brain drain effect and by taking away qualifications and skills just when these countries are at their most vulnerable. Developing countries have, of course, to make some efforts, but developed countries must provide more support and increase their political will to combat climate change and its damaging consequences above all in the poorest countries, for it is the latter, rather than more affluent countries, which contribute the least towards climate change and yet which suffer the greatest consequences. 


\section{References}

Baechler, G. (1999b): Environmental degradation and violent conflict: hypotheses, research agendas and theory building Ecology, In M. Suliman: Ecology, Politics and Violent Conflict, Zed Books, London and New York (1999), 76-112.

Barnett, J. and Adger, W. N. (2007): "Climate change, human security and violent conflict", Political Geography, 26 (6), 639-655.

Barnett, J. and Jones, R. (2002): "Forced migration: the influence of environmental security", Global Change, 7 (4), 3.

Bates, D. (2002): "Environmental Refugees? Classifying Human Migrations Caused by Environmental Change”, Population and Environment, 23 (5), 465-477.

Benson, C. and Clay, E. (1998): “The impact of drought on sub-Saharan Economies”, World Bank Technical Paper No. 401, Technical report, Washington DC, World Bank.

Bridgman, H. (1983): "Could climatic change have had an influence on the polynesian migrations?", Palaeogeography, Palaeoclimatology, Palaeoecology, 41, 193-206.

Comenetz, J. and Caviedes, C. (2002): “Climate variability, political crises, and historical population displacements in Ethiopia”, Environmental Hazards, 4, 113-127.

CRED (2010): EM-DAT. Centre for Research on the Epidemiology of Disasters, Brussels: University of Louvain.

Docquier, F. and Marfouk, A. (2006): International Migration by Educational Attainment, In C. Ozden and M. Schiff (eds). International Migration, Remittances and the Brain Drain, Palgrave Macmillan: New York (2006).Dudley L. Poston, D.; Zhang, L.; Gotcher, D. and Gu, Y. (2009): “The effect of climate on migration: United States, 1995-2000”, Social Science Research, 38, 743-753. 
Dyson, T. (2006): “On Development, Demography and Climate Change: The End of the World as We Know it?", Population and Environment, 27(2), 117-149.

El-Hinnawi, E. (1985): "Environmental Refugees”, Technical report, Nairobi, Kenya: United Nations Environmental Programme.

Ghatak, S.; Levine, P. \& Price, S. W. (1996), "Migration Theories and Evidence: an Assessment”, Journal of Economic Surveys 10(2), 159-198.

Gleditsch et al. (2002), Uppsala Conflict Data Program (UCDP)/Centre for the Study of Civil Wars, International Peace Research Institute, Oslo (PRIO) Armed Conflict Dataset Codebook.

Harris, J. R. and Todaro, M. P. (1970): "Migration, Unemployment and Development: A Two-Sector Analysis", The American Economic Review, 60(1), 126-142.

Huang, C. and Su, H. (2009): "Climate change and Zhou relocations in early Chinese history", Journal of Historical Geography, 35, 297-310.

Hunter, L. (2005): "Migration and Environmental Hazards", Population and Environment, 26 (4), 273-302.

Hunter, L.; White, M. and Sutton, J. (2003), "Environmental Hazards, Migration, and Race", Population and Environment, 25 (1), 23-39.

Ikeme, J. (2003): “Climate Change Adaptational Deficiencies in Developing Countries: the Case of Sub-Saharan Africa”, Mitigation and Adaptation Strategies for Global Change, 8(1), 29-52.

IMF (2003): "Fund assistance for countries facing exogeneous shocks", prepared by the Policy Development and Review Departement (In consultation with the Area, Finance and Fiscal Affairs Departements) International Monetary Fund, Technical report, Washington,DC, IMF. 
IOM (2007): "Migration and the Environment", IOM (International Organization for Migration), Technical report, International Organization for Migration, Geneva.

IPCC (2007): Fourth Assessment Report: Climate Change 2007: The AR4 Synthesis Report, Geneva: IPCC.

Khasnis, A. and Nettleman, M. (2005): “Global Warming and Infectious Disease”, Archives of Medical Research, 36, 689-696.

Marchiori, L. and Schumacher, I. (2011): "When nature rebels: international migration, climate change, and inequality", Journal of Population Economics, 24, 569-600.

McGregor, J. (1994): “Climate change and involuntary migration: implications for food security”, Food Policy, 19 (2), 120-132.

Mcleman, R. and Smit, B. (2006): "Migration as an adaptation to Climate Change", Climatic Change, 76, 31-53.

Meehl, G. A.; Washington, W. M.; Santer, B. D.; Collins, W. D.; Arblaster, J. M.; Hu, A.; Lawrence, D. M.; Teng, H.; Buja, L. E. and Strand, W. G. (2006): "Climate Change Projections for the Twenty-First Century and Climate Change Commitment in the CCSM3", Journal of Climate, 19, 2597-2616.

Meier, P., D. Bond. 2007. "The Influence of Environmental Factors on Conflict in the Horn of Africa," Journal of Political Geography (in press).

Meze-Hausken, E. (2000): "Migration caused by climate change: how vulnerable are people in dryland areas?", Mitigation and Adaptation Strategies for Global Change, 5, 379-406.

Mortreux, C. \& Barnett, J. (2009): "Climate change, migration and adaptation in Funafuti, Tuvalu", Global Environmental Change, 19, 105-112.

Myers, N. (2005): "Environmental Refugees, an emergent security issue", Paper presented to the 13th Economic Forum, Prague, Czech Republic, 23-27 May 2005 
Naude, W. (2008): “Conflict, Disasters, and No Jobs: Reasons for International Migration from Sub-Saharan Africa”, Working paper RP2008/85, World Institute for Development Economic Research (UNU-WIDER).

Ngecu, W. and Mathu, E. (1999): “The El Nino-triggered landslides and their socioeconomic impact on Kenya", Environmental Geology, 38 (4), 277-284.

Niasse, M. (June 2005): “Climate-Induced Water Conflict Risks in West Africa: Recognizing and Coping with Increasing Climate Impacts on Shared Watercourses", paper presented to the International Workshop on Human Security and Climate Change, Asker, Oslo.

Oliver-Smith, A. (2009): Sea level rise and the vulnerability of coastal peoples: responding to the local challenges of global climate change in the 21 st century, InterSections No. 7, United Nations University Institute for Environment and Human Security, Bonn.

Perch-Nielsen, S.; Bättig, M. and Imboden, D. (2008): "Exploring the link between climate change and migration", Climatic Change, 91, 375-393.

Rehdanz, K. and Maddison, D. (2005): "Climate and happiness", Ecological Economics, 52(1), 111-125.

Reuveny, R. (2007): "Climate change-induced migration and violent conflict", Political Geography, 26, 656-673.

Reuveny, R. and Moore, W. H. (2009): "Does Environmental Degradation Influence Migration? Emigration to Developed Countries in the Late 1980s and 1990s”, Social Science Quarterly, 90(3), 461-479.

Schrag, S. and Wiener, P. (1995): "Emerging infectious disease: what are the relative roles of ecology and evolution?", Trends in Ecology \& Evolution, 10 (8).

Schiff, M. and Sjöblom, M. (2008): Panel Data on International Migration 1975-2000, World Bank databases. 
Smith, P. (2007): Climate Change, Mass Migration and the Military Response, Foreign Policy Research Institute.

Stark, O. (1991): “The Migration of Labor”, London: Basil Blackwell.

Stark, O. and Levhari, D. (1982): “On Migration and Risk in LDCs”, Economic Development and Cultural Change, 31(1), 191-96.

Stark, O. and Lucas, R. E. B. (1988): "Migration, Remittances, and the Family", Economic Development and Cultural Change, 36(3), pp. 465-481.

Stern, N. (2007): "The Economics of Climate Change": The Stern Review, Cambridge University Press.

Swain, A. (Dec.1993): “Conflicts over Water: The Ganges Water Dispute”, Security Dialogue (Oslo), 24(4), 429-439.

Swain, A. (Dec.1996): "Environmental Migration and Conflict Dynamics: Focus on Developing Regions", Third World Quarterly, 17 (5), 959-973.

Swain, A. (May. 1996): "Displacing the Conflict: Environmental Destruction in Bangladesh and Ethnic Conflict in India”, Journal of Peace Research, 33 (2), 189-204.

United Nations Population Division (2009): International Migration flows to and from selected countries: the 2008 revision.

Warner, K. (2010): “Global environmental change and migration: Governance challenges”, Global Environmental Change, 20 (3), 402-413.

Washington, R.; Harrison, M.; Conway, D.; Black, E.; Challinor, A.; Grimes, D.; Jones, R.; Morse, A.; Kay, G. and Todd, M. (2006): “African Climate change: taking the shorter Route", Bulletin of the American Meteorological Society, 87, 10, 1355-1366. 
Table 1: Fixed effects estimation of the Effect of natural disaster on international migration

\begin{tabular}{|c|c|c|c|c|c|}
\hline \multirow[b]{2}{*}{ Indep. Var. } & \multicolumn{5}{|c|}{ Dependent variable: Net migration } \\
\hline & $(1)$ & (2) & (3) & (4) & $(5)$ \\
\hline Number of natural disasters & $\begin{array}{c}0.095^{* * * *} \\
(3.20)\end{array}$ & & & & \\
\hline Number of meteorological disasters & & $\begin{array}{c}0.290^{* *} \\
(2.37)\end{array}$ & & & \\
\hline Number of hydrological disasters & & & $\begin{array}{c}0.298^{* * *} \\
(2.85)\end{array}$ & & \\
\hline Number of climatological disasters & & & & $\begin{array}{c}-0.049 \\
(0.10)\end{array}$ & \\
\hline Number of climatological disasters lag & & & & & $\begin{array}{c}1.378^{* * *} \\
(2.16)\end{array}$ \\
\hline Log GDP per capita & $\begin{array}{c}-5.516^{*} \\
(1.70)\end{array}$ & $\begin{array}{c}-5.497^{*} \\
(1.68)\end{array}$ & $\begin{array}{c}-5.867^{*} \\
(1.79)\end{array}$ & $\begin{array}{l}-4.715 \\
(1.38)\end{array}$ & $\begin{array}{c}-5.307^{*} \\
(1.66)\end{array}$ \\
\hline Young population & $\begin{array}{c}-0.164 \\
(0.59)\end{array}$ & $\begin{array}{c}-0.166 \\
(0.61)\end{array}$ & $\begin{array}{c}-0.156 \\
(0.56)\end{array}$ & $\begin{array}{c}-0.243 \\
(0.90)\end{array}$ & $\begin{array}{c}-0.148 \\
(0.55)\end{array}$ \\
\hline Log Population Density & $\begin{array}{c}-2.229 \\
(0.80)\end{array}$ & $\begin{array}{r}-1.505 \\
(0.57)\end{array}$ & $\begin{array}{c}-2.391 \\
(0.86)\end{array}$ & $\begin{array}{c}-1.321 \\
(0.48)\end{array}$ & $\begin{array}{c}-2.126 \\
(0.76)\end{array}$ \\
\hline Percentage Arable area & $\begin{array}{c}-0.508 \\
(0.90)\end{array}$ & $\begin{array}{c}-0.509 \\
(0.89)\end{array}$ & $\begin{array}{c}-0.498 \\
(0.89)\end{array}$ & $\begin{array}{c}-0.504 \\
(0.87)\end{array}$ & $\begin{array}{l}-0.414 \\
(0.73)\end{array}$ \\
\hline Political rights & $\begin{array}{l}0.021 \\
(0.05)\end{array}$ & $\begin{array}{l}0.021 \\
(0.05)\end{array}$ & $\begin{array}{l}0.024 \\
(0.06)\end{array}$ & $\begin{array}{l}0.006 \\
(0.02)\end{array}$ & $\begin{array}{l}0.022 \\
(0.06)\end{array}$ \\
\hline Civil war & $\begin{array}{c}0.822^{* *} \\
(2.21)\end{array}$ & $\begin{array}{c}0.904^{* *} \\
(2.39)\end{array}$ & $\begin{array}{c}0.778^{* * *} \\
(2.10)\end{array}$ & $\begin{array}{c}0.895^{* * *} \\
(2.38)\end{array}$ & $\begin{array}{c}0.833^{* *} \\
(2.27)\end{array}$ \\
\hline Constant & $\begin{array}{c}57.026 \\
(1.52)\end{array}$ & $\begin{array}{c}54.459 \\
(1.47)\end{array}$ & $\begin{array}{c}59.259 \\
(1.56)\end{array}$ & $\begin{array}{c}52.772 \\
(1.38)\end{array}$ & $\begin{array}{c}53.201 \\
(1.45)\end{array}$ \\
\hline $\begin{array}{l}\text { Observations } \\
\text { countries }\end{array}$ & $\begin{array}{c}435 \\
88\end{array}$ & $\begin{array}{l}435 \\
88\end{array}$ & $\begin{array}{c}435 \\
88\end{array}$ & $\begin{array}{c}435 \\
88\end{array}$ & $\begin{array}{l}435 \\
88\end{array}$ \\
\hline $\mathrm{R}^{2}$ & 0.063 & 0.065 & 0.067 & 0.057 & 0.076 \\
\hline
\end{tabular}

Note: Absolute $t$ statistics in parentheses. ${ }^{*} p<0.1,{ }^{* *} p<0.05,{ }^{* * *} p<0.01$ 
Table 2: Fixed effects estimation of the effect of lagged natural disaster on international migration

\begin{tabular}{lcccc}
\hline \multirow{2}{*}{ Indep. Var. } & \multicolumn{3}{c}{ Dependent variable: Net migration } \\
\cline { 2 - 5 } Number of Natural Disasters lag & $(1)$ & $(2)$ & $(3)$ & $(4)$ \\
& $0.110^{* *}$ & & & \\
Number of meteorological disasters lag & $(2.06)$ & & \\
& & $0.175^{* *}$ & \\
Number of hydrological disasters lag & & $(2.26)$ & & \\
& & & $0.257^{*}$ \\
Number of climatological disasters lag & & & $(1.87)$ & \\
& & & & $1.378^{* *}$ \\
Log GDP per capita & & & & $(2.16)$ \\
& & & & \\
Young population & -5.575 & -5.229 & -5.494 & $-5.307^{*}$ \\
& $(1.65)$ & $(1.59)$ & $(1.63)$ & $(1.66)$ \\
Log population density & -0.164 & -0.202 & -0.154 & -0.148 \\
& $(0.60)$ & $(0.72)$ & $(0.55)$ & $(0.55)$ \\
Percentage arable area & -1.994 & -1.467 & -1.841 & -2.126 \\
& $(0.72)$ & $(0.55)$ & $(0.68)$ & $(0.76)$ \\
Political rights & -0.491 & -0.497 & -0.502 & -0.414 \\
Civil war & $(0.87)$ & $(0.88)$ & $(0.89)$ & $(0.73)$ \\
& 0.007 & 0.014 & 0.000 & 0.022 \\
Constant & $(0.02)$ & $(0.04)$ & $(0.00)$ & $(0.06)$ \\
& $0.836^{* *}$ & $0.876^{* *}$ & $0.828^{* *}$ & $0.833^{* *}$ \\
Observations & $(2.26)$ & $(2.32)$ & $(2.21)$ & $(2.27)$ \\
Countries & 56.453 & 54.352 & 55.257 & 53.201 \\
$\mathrm{R}^{2}$ & $(1.48)$ & $(1.44)$ & $(1.46)$ & $(1.45)$ \\
\hline
\end{tabular}

Note: Absolute $t$ statistics in parentheses. ${ }^{*} p<0.1,{ }^{* *} p<0.05,{ }^{* * *} p<0.01$ 
Table 3: Fixed effects estimation of the effect of natural disaster on international migration (other measures)

\begin{tabular}{|c|c|c|c|c|c|c|c|c|c|}
\hline \multirow[b]{2}{*}{ Indep. Var. } & \multicolumn{9}{|c|}{ Dependent variable: Net migration } \\
\hline & $(1)$ & $(2)$ & $(3)$ & (4) & $(5)$ & $(6)$ & $(7)$ & $(8)$ & $(9)$ \\
\hline Log meteorological damages & $\begin{array}{c}0.221 \\
(2.88)\end{array}$ & & & & & & & & \\
\hline Log meteorological death & & $\begin{array}{c}0.221^{* * * *} \\
(2.88)\end{array}$ & & & & & & & \\
\hline Log meteorological total affected & & & $\begin{array}{c}0.407^{* * *} \\
(2.76)\end{array}$ & & & & & & \\
\hline Log hydrological damages & & & & $\begin{array}{c}0.187^{* *} \\
(2.33)\end{array}$ & & & & & \\
\hline Log hydrological death & & & & & $\begin{array}{l}0.337 \\
(1.48)\end{array}$ & & & & \\
\hline Log hydrological total affected & & & & & & $\begin{array}{r}-0.000 \\
(0.00)\end{array}$ & & & \\
\hline Log climatological damages & & & & & & & $\begin{array}{l}0.029 \\
(0.24)\end{array}$ & & \\
\hline Log climatological death & & & & & & & & $\begin{array}{l}0.017 \\
(0.09)\end{array}$ & \\
\hline Log climatological total affected & & & & & & & & & $\begin{array}{c}-0.040 \\
(0.56)\end{array}$ \\
\hline Log GDP per capita & $\begin{array}{l}-4.740 \\
(1.45)\end{array}$ & $\begin{array}{l}-4.756 \\
(1.44)\end{array}$ & $\begin{array}{l}-4.756 \\
(1.44)\end{array}$ & $\begin{array}{c}-4.951 \\
(1.51)\end{array}$ & $\begin{array}{c}-4.890 \\
(1.53)\end{array}$ & $\begin{array}{c}-4.744 \\
(1.45)\end{array}$ & $\begin{array}{l}-4.969 \\
(1.54)\end{array}$ & $\begin{array}{l}-4.829 \\
(1.50)\end{array}$ & $\begin{array}{r}-4.903^{\prime} \\
(1.67)\end{array}$ \\
\hline Young population & $\begin{array}{l}-0.224 \\
(0.84)\end{array}$ & $\begin{array}{l}-0.236 \\
(0.82)\end{array}$ & $\begin{array}{l}-0.261 \\
(0.94)\end{array}$ & $\begin{array}{c}-0.184 \\
(0.64)\end{array}$ & $\begin{array}{c}-0.230 \\
(0.79)\end{array}$ & $\begin{array}{l}-0.237 \\
(0.82)\end{array}$ & $\begin{array}{c}-0.172 \\
(0.61)\end{array}$ & $\begin{array}{l}-0.207 \\
(0.73)\end{array}$ & $\begin{array}{c}-0.144 \\
(0.55)\end{array}$ \\
\hline Log population density & $\begin{array}{r}-1.300 \\
(0.50)\end{array}$ & $\begin{array}{l}-1.354 \\
(0.52)\end{array}$ & $\begin{array}{l}-1.285 \\
(0.48)\end{array}$ & $\begin{array}{r}-1.797 \\
(0.66)\end{array}$ & $\begin{array}{c}-2.042 \\
(0.86)\end{array}$ & $\begin{array}{r}-1.340 \\
(0.59)\end{array}$ & $\begin{array}{c}-1.346 \\
(0.52)\end{array}$ & $\begin{array}{l}-1.747 \\
(0.67)\end{array}$ & $\begin{array}{r}-2.000 \\
(0.77)\end{array}$ \\
\hline Percentage arable area & $\begin{array}{l}-0.509 \\
(0.89)\end{array}$ & $\begin{array}{l}-0.503 \\
(0.88)\end{array}$ & $\begin{array}{l}-0.504 \\
(0.89)\end{array}$ & $\begin{array}{c}-0.521 \\
(0.92)\end{array}$ & $\begin{array}{c}-0.554 \\
(0.94)\end{array}$ & $\begin{array}{c}-0.503 \\
(0.86)\end{array}$ & $\begin{array}{c}-0.528 \\
(0.93)\end{array}$ & $\begin{array}{l}-0.506 \\
(0.89)\end{array}$ & $\begin{array}{l}-0.519 \\
(0.92)\end{array}$ \\
\hline Political rights & $\begin{array}{l}0.007 \\
(0.02)\end{array}$ & $\begin{array}{l}0.005 \\
(0.01)\end{array}$ & $\begin{array}{l}0.012 \\
(0.03)\end{array}$ & $\begin{array}{l}0.027 \\
(0.07)\end{array}$ & $\begin{array}{l}0.003 \\
(0.01)\end{array}$ & $\begin{array}{l}0.006 \\
(0.02)\end{array}$ & $\begin{array}{l}0.010 \\
(0.03)\end{array}$ & $\begin{array}{l}0.044 \\
(0.11)\end{array}$ & $\begin{array}{l}0.047 \\
(0.12)\end{array}$ \\
\hline Civil war & $\begin{array}{c}0.902^{* * *} \\
(2.25)\end{array}$ & $\begin{array}{c}0.890^{* * *} \\
(2.30)\end{array}$ & $\begin{array}{c}0.894^{* *} \\
(2.32)\end{array}$ & $\begin{array}{c}0.888^{* * *} \\
(2.32)\end{array}$ & $\begin{array}{c}0.871^{\text {*** }} \\
(2.24)\end{array}$ & $\begin{array}{c}0.893^{* * *} \\
(2.22)\end{array}$ & $\begin{array}{c}0.910^{* * *} \\
(2.38)\end{array}$ & $\begin{array}{c}0.959^{* * *} \\
(2.49)\end{array}$ & $\begin{array}{c}0.934^{*} \\
(2.53)\end{array}$ \\
\hline Constant & $\begin{array}{r}52.015 \\
(1.43) \\
\end{array}$ & $\begin{array}{c}52.822 \\
(1.38) \\
\end{array}$ & $\begin{array}{r}53.767 \\
(1.42) \\
\end{array}$ & $\begin{array}{c}52.926 \\
(1.39) \\
\end{array}$ & $\begin{array}{c}55.871 \\
(1.52) \\
\end{array}$ & $\begin{array}{c}52.738 \\
(1.43) \\
\end{array}$ & $\begin{array}{c}51.218 \\
(1.37) \\
\end{array}$ & $\begin{array}{c}52.606 \\
(1.41) \\
\end{array}$ & $\begin{array}{r}50.879 \\
(1.47) \\
\end{array}$ \\
\hline Observations & 435 & 435 & 435 & 435 & 435 & 435 & 435 & 435 & 435 \\
\hline Countries & 88 & 88 & 88 & 88 & 88 & 88 & 88 & 88 & 88 \\
\hline $\mathrm{R}^{2}$ & 0.057 & 0.057 & 0.058 & 0.065 & 0.062 & 0.057 & 0.065 & 0.065 & 0.088 \\
\hline
\end{tabular}


Table 4: Fixed effects estimation of the effect of natural disaster on international migration according to educational level

\begin{tabular}{lccc}
\hline & \multicolumn{3}{c}{ Dependent variable } \\
\cline { 2 - 4 } Indep. Var. & $\begin{array}{c}(1) \\
\text { Low } \\
\text { education }\end{array}$ & $\begin{array}{c}\text { Medium } \\
\text { education }\end{array}$ & $\begin{array}{c}\text { High } \\
\text { education }\end{array}$ \\
\hline \multirow{2}{*}{ Number of natural disasters } & & & \\
& -0.00002 & 0.00007 & $0.001^{* * *}$ \\
Log GDP per capita & $(0.98)$ & $(0.13)$ & $(2.27)$ \\
& $-0.005^{*}$ & $-0.014^{*}$ & $-0.073^{* * *}$ \\
Young population & $(1.84)$ & $(1.70)$ & $(3.17)$ \\
& -0.001 & -0.003 & -0.001 \\
Population density & $(1.55)$ & $(1.34)$ & $(0.28)$ \\
& -0.001 & -0.003 & -0.024 \\
Percentage arable area & $(0.33)$ & $(0.27)$ & $(0.61)$ \\
& 0.001 & 0.001 & $0.006^{*}$ \\
Political rights & $(0.88)$ & $(0.65)$ & $(1.70)$ \\
Civil war & -0.001 & -0.000 & 0.003 \\
& $(1.64)$ & $(0.20)$ & $(0.83)$ \\
Constant & 0.000 & 0.000 & 0.005 \\
& $(0.05)$ & $(0.29)$ & $(1.09)$ \\
\hline Observations & $0.104^{*}$ & $0.245^{*}$ & $0.634^{* *}$ \\
Countries & $(1.67)$ & $(1.71)$ & $(2.31)$ \\
$\mathrm{R}^{2}$ & 435 & 435 & 435 \\
\hline
\end{tabular}

Note: Absolute $t$ statistics in parentheses. ${ }^{*} p<0.1,{ }^{* *} p<0.05,{ }^{* * *} p<0.01$ 
Table 5: Fixed effects estimation of the effect of natural disaster on high educated migration rate according to geographical regions

\begin{tabular}{|c|c|c|c|c|c|c|}
\hline \multirow[b]{2}{*}{ Indep. Var. } & \multicolumn{6}{|c|}{ Dependent variable: High educated migration rate } \\
\hline & $(1)$ & $(2)$ & (3) & (4) & $(5)$ & $(6)$ \\
\hline Number of natural disasters & $\begin{array}{c}0.001^{* * * *} \\
(2.97)\end{array}$ & $\begin{array}{l}0.002 \\
(1.46)\end{array}$ & $\begin{array}{l}0.001^{* *} \\
(2.25)\end{array}$ & $\begin{array}{c}0.001^{* *} \\
(2.09)\end{array}$ & $\begin{array}{l}0.001^{* *} \\
(2.42)\end{array}$ & $\begin{array}{l}0.001 \\
(1.58)\end{array}$ \\
\hline (Disaster)x(SSA) & $\begin{array}{c}-0.002 \\
(0.98)\end{array}$ & & & & & \\
\hline (Disaster)x(EAP) & & $\begin{array}{l}-0.001 \\
(0.67)\end{array}$ & & & & \\
\hline (Disaster)x(ECA) & & & $\begin{array}{l}0.008^{*} \\
(1.84)\end{array}$ & & & \\
\hline (Disaster) $\mathrm{x}(\mathrm{LAC})$ & & & & $\begin{array}{c}0.004^{* *} \\
(2.51)\end{array}$ & & \\
\hline (Disaster)x(MENA) & & & & & $\begin{array}{c}-0.003^{* *} \\
(2.52)\end{array}$ & \\
\hline (Disaster)x(SA) & & & & & & $\begin{array}{l}0.002^{*} \\
(1.73)\end{array}$ \\
\hline Log GDP per capita & $\begin{array}{c}-0.076^{* * *} \\
(3.52)\end{array}$ & $\begin{array}{c}-0.071^{* * * *} \\
(2.98)\end{array}$ & $\begin{array}{c}-0.072^{* * *} \\
(3.12)\end{array}$ & $\begin{array}{c}-0.069^{* * * *} \\
(2.89)\end{array}$ & $\begin{array}{c}-0.075^{* * *} \\
(3.32)\end{array}$ & $\begin{array}{c}-0.076^{* * * *} \\
(3.41)\end{array}$ \\
\hline Young population & $\begin{array}{l}-0.000 \\
(0.05)\end{array}$ & $\begin{array}{l}-0.001 \\
(0.35)\end{array}$ & $\begin{array}{l}-0.000 \\
(0.21)\end{array}$ & $\begin{array}{l}-0.000 \\
(0.08)\end{array}$ & $\begin{array}{l}-0.001 \\
(0.44)\end{array}$ & $\begin{array}{l}-0.001 \\
(0.45)\end{array}$ \\
\hline Log population density & $\begin{array}{c}-0.015 \\
(0.32)\end{array}$ & $\begin{array}{l}-0.031 \\
(0.66)\end{array}$ & $\begin{array}{c}-0.023 \\
(0.58)\end{array}$ & $\begin{array}{l}-0.025 \\
(0.64)\end{array}$ & $\begin{array}{l}-0.023 \\
(0.57)\end{array}$ & $\begin{array}{l}-0.030 \\
(0.74)\end{array}$ \\
\hline Percentage arable area & $\begin{array}{l}0.006^{*} \\
(1.74)\end{array}$ & $\begin{array}{l}0.006^{*} \\
(1.73)\end{array}$ & $\begin{array}{l}0.006^{*} \\
(1.68)\end{array}$ & $\begin{array}{l}0.005 \\
(1.60)\end{array}$ & $\begin{array}{l}0.006 \\
(1.65)\end{array}$ & $\begin{array}{l}0.007^{* *} \\
(2.01)\end{array}$ \\
\hline Political rights & $\begin{array}{l}0.003 \\
(0.85)\end{array}$ & $\begin{array}{l}0.004 \\
(0.85)\end{array}$ & $\begin{array}{l}0.004 \\
(0.86)\end{array}$ & $\begin{array}{l}0.004 \\
(0.95)\end{array}$ & $\begin{array}{l}0.004 \\
(0.87)\end{array}$ & $\begin{array}{l}0.004 \\
(0.86)\end{array}$ \\
\hline Civil war & $\begin{array}{l}0.005 \\
(1.08)\end{array}$ & $\begin{array}{l}0.005 \\
(1.12)\end{array}$ & $\begin{array}{l}0.005 \\
(1.12)\end{array}$ & $\begin{array}{l}0.006 \\
(1.24)\end{array}$ & $\begin{array}{l}0.005 \\
(1.14)\end{array}$ & $\begin{array}{l}0.005 \\
(1.08)\end{array}$ \\
\hline Constant & $\begin{array}{c}0.600^{* * *} \\
(2.11)\end{array}$ & $\begin{array}{c}0.645^{* * *} \\
(2.28) \\
\end{array}$ & $\begin{array}{l}0.618^{* * *} \\
(2.22)\end{array}$ & $\begin{array}{l}0.593^{* *} \\
(2.14)\end{array}$ & $\begin{array}{l}0.661^{* * *} \\
(2.43)\end{array}$ & $\begin{array}{l}0.667^{* *} \\
(2.49)\end{array}$ \\
\hline Observations & 435 & 435 & 435 & 435 & 435 & 435 \\
\hline Countries & 88.000 & 88.000 & 88.000 & 88.000 & 88.000 & 88.000 \\
\hline $\mathrm{R}^{2}$ & 0.094 & 0.092 & 0.092 & 0.096 & 0.095 & 0.099 \\
\hline
\end{tabular}




\section{Appendix A: Definitions}

\section{A.1 Intergovernmental Panel on Climate Change (IPCC, 2007)) definition}

"Climate change in IPCC usage refers to a change in the state of the climate that can be identified (e.g. using statistical tests) by changes in the mean and/or the variability of its properties, and that persists for an extended period, typically decades or longer. It refers to any change in climate over time, whether due to natural variability or as a result of human activity. This usage differs from that in the United Nations Framework Convention on Climate Change (UNFCCC), where climate change refers to a change of climate that is attributed directly or indirectly to human activity that alters the composition of the global atmosphere and that is in addition to natural climate variability observed over comparable time periods".

\section{A.2 Definitions of environmental migrants/ refugees}

El Hinnawi (1985): Environmental migrants are "people who have been forced to leave their traditional habitat, temporarily or permanently, because of a marked environmental disruption that jeopardized their existence or seriously affected the quality of their life".

Bates (2002) criticizes the definition and classification of environmental migration of El-Hinnawi in the UNEP 1985 report. For Bates this definition does not provide generic criteria distinguishing environmental refugees from other types of migrants and not specify differences between types of environmental refugees. It makes no distinction between refugees who flee volcanic eruptions and those who gradually leave their homes as soil quality declines. For Bates "a working definition of environmental refugees includes people who migrate from their usual residence due to changes in their ambient non-human environment". This definition remains necessarily vague in order to incorporate the two most important features of environmental refugees: the transformation of the environment to one less suitable for human occupation and the acknowledgment that this causes migration. The author establishes a classification of environmental refugees according to the causes of migration. One distinguishes three categories of human migration due to environmental change: (i) Environmental refugees due to disasters caused by natural or technological events. Those people are short-term refugees in geographically limited areas. Natural disasters, which include hurricanes, floods, tornadoes, earthquakes or events that made a place inhabitable temporarily or permanently are considered, alongside technological disasters 
resulting from human choices, as unintentional migration. (ii) Environmental refugees due to expropriation of the environment are people who leave their habitat permanently to allow land use. The expropriation of the environment can be due on one hand to economic development such as the construction of hydroelectric dams or roads and, on the other hand, to warfare and the destruction of the environment, strategically displacing the population during war incorporating, for instance, land mines. (iii) Environmental refugees due to the deterioration of the environment: the migration of these people is caused by the anthropogenic degradation of their environment: one talks about environmental migrants. The effect of environmental degradation ripples through the local economy context to affect migration. While disasters and expropriation refugees do not possess any real means to control environmental change, environmental migrants can decide the strategies to cope with environmental change. 


\section{Appendix B: Tables}

Table B.1: Variables definition and sources

\begin{tabular}{|c|c|c|}
\hline Variables & Definition & Source \\
\hline Net migration & $\begin{array}{l}\text { The difference between the total number of } \\
\text { emigrants minus the number of immigrants divided } \\
\text { by the person-years lived by the population }\end{array}$ & $\begin{array}{l}\text { United Nations } \\
\text { Population Division }\end{array}$ \\
\hline $\begin{array}{l}\text {-Low educational migration rate } \\
\text {-Medium educational migration } \\
\text { rate } \\
\text {-High educational migration rate }\end{array}$ & $\begin{array}{l}\text { Stocks of migrants from sending countries to the } \\
6 \text { key receiving countries in the OECD (Australia, } \\
\text { Canada, France, Germany, UK, USA), by } \\
\text { educational level, divided by the stock of adults } \\
(+25) \text { corresponding to the same educational level, } \\
\text { in the country of origin }+ \text { The stock of migrants of } \\
\text { sending countries }\end{array}$ & $\begin{array}{l}\text { M. Schiff and M.C } \\
\text { Sjoblom (World Bank } \\
\text { Databases) }\end{array}$ \\
\hline Number of natural disasters & $\begin{array}{l}\text { Number of natural disasters (a unique disaster } \\
\text { number for each event) }\end{array}$ & CRED 2010 \\
\hline $\begin{array}{l}\text { Number of meteorological } \\
\text { disasters (storm) }\end{array}$ & $\begin{array}{l}\text { Number of events caused by small to meso scale } \\
\text { atmospheric processes (in the spectrum from } \\
\text { minutes to days). The main type of disaster is } \\
\text { storms. }\end{array}$ & CRED 2010 \\
\hline Number of hydrological disasters & $\begin{array}{l}\text { Number of events caused by deviations in the } \\
\text { normal water cycle and/or overflow of bodies of } \\
\text { water caused by wind set-up. The main types of } \\
\text { disaster are flood and wet mass movement }\end{array}$ & CRED 2010 \\
\hline $\begin{array}{l}\text { Number of climatological } \\
\text { disasters }\end{array}$ & $\begin{array}{l}\text { Number of events caused by meso to macro scale } \\
\text { processes (in the spectrum from intra-seasonal to } \\
\text { multi-decadal climate variability). The main type } \\
\text { of disasters are extreme temperature, drought and } \\
\text { wildfire }\end{array}$ & CRED 2010 \\
\hline Meteorological damages & $\begin{array}{l}\text { Estimated damages due to meteorological disasters } \\
\text { (given in US\$) }\end{array}$ & CRED 2010 \\
\hline Meteorological death & $\begin{array}{l}\text { Number of persons confirmed as dead and persons } \\
\text { missing and presumed dead due to meteorological } \\
\text { disasters }\end{array}$ & CRED 2010 \\
\hline Meteorological total affected & $\begin{array}{l}\text { Sum of injured, homeless and affected due to } \\
\text { meteorological disasters }\end{array}$ & CRED 2010 \\
\hline Hydrological damages & $\begin{array}{l}\text { Estimated damages due to hydrological disasters } \\
\text { (given in US\$) }\end{array}$ & CRED 2010 \\
\hline Hydrological death & $\begin{array}{l}\text { Number of persons confirmed as dead and persons } \\
\text { missing and presumed dead due to hydrological } \\
\text { disasters }\end{array}$ & CRED 2010 \\
\hline Hydrological total affected & $\begin{array}{l}\text { Sum of injured, homeless and affected due to } \\
\text { hydrological disasters }\end{array}$ & CRED 2010 \\
\hline Climatological damages & $\begin{array}{l}\text { Estimated damages due to climatological disasters } \\
\text { (given in US\$) }\end{array}$ & CRED 2010 \\
\hline Climatological death & $\begin{array}{l}\text { Number of persons confirmed as dead and persons } \\
\text { missing and presumed dead due to climatological } \\
\text { disasters }\end{array}$ & CRED 2010 \\
\hline Climatological total affected & $\begin{array}{l}\text { Sum of injured, homeless and affected due to } \\
\text { climatological disasters }\end{array}$ & CRED 2010 \\
\hline GDP per capita & Gross Domestic Product per capita & $\begin{array}{l}\text { Online World bank } \\
\text { WDI }\end{array}$ \\
\hline Young population & Percentage of population under 14 years old & $\begin{array}{l}\text { Online World bank } \\
\text { WDI }\end{array}$ \\
\hline Population density & Number of inhabitants per $\mathrm{km}^{2}$ & $\begin{array}{l}\text { Online World bank } \\
\text { WDI }\end{array}$ \\
\hline
\end{tabular}


Table B.1 continued

\begin{tabular}{|l|l|l|}
\hline \multicolumn{1}{|c|}{ Variables } & \multicolumn{1}{|c|}{ Definition } & \multicolumn{1}{|c|}{ Source } \\
\hline Percentage arable area & Arable area as percentage of total land area & $\begin{array}{l}\text { Online World bank } \\
\text { WDI }\end{array}$ \\
\hline Political rights & $\begin{array}{l}\text { Political Rights are measured on a one-to-seven } \\
\text { scale, with one representing the highest degree of } \\
\text { Freedom and seven the lowest. }\end{array}$ & Freedom House \\
\hline Civil war & $\begin{array}{l}\text { Dummy variable taking the value 1 for a } \\
\text { minimum of 25 battle-related deaths per year and 0 } \\
\text { otherwise. }\end{array}$ & $\begin{array}{l}\text { UCDP/PRIO Armed } \\
\text { Conflict Dataset }\end{array}$ \\
\hline
\end{tabular}


Table B.2: Summary Statistics

\begin{tabular}{|c|c|c|c|c|c|}
\hline Variables & Mean & Stand. Dev. & Min & Max & $\mathrm{N}$ \\
\hline Net Migration & 2.424828 & 8.771825 & -57.1 & 53.4 & 435 \\
\hline Low education migration rate & 0.012835 & 0.0283228 & 0.0000242 & 0.208263 & 435 \\
\hline Medium education migration rate & 0.0455184 & 0.093226 & 0.0000273 & 0.5790774 & 435 \\
\hline High education migration rate & 0.1780199 & 0.2031705 & 0.0003033 & 1 & 435 \\
\hline Number of natural disasters & 7.151724 & 12.76552 & 0 & 109 & 435 \\
\hline Number of meteorological disasters & 1.641379 & 5.11212 & 0 & 37 & 435 \\
\hline Number of hydrological disasters & 2.503448 & 4.868488 & 0 & 40 & 435 \\
\hline Number of climatological disasters & 0.8206897 & 1.223817 & 0 & 9 & 435 \\
\hline Meteorological damages & 20974.55 & 179698.8 & 0 & 2890000 & 435 \\
\hline Meteorological death & 59.75172 & 736.3724 & 0 & 15100 & 435 \\
\hline Meteorological total affected & 119573.9 & 697670.5 & 0 & 6570000 & 435 \\
\hline Hydrological damages & 35994.96 & 337246.4 & 0 & 6720000 & 435 \\
\hline Hydrological death & 70.89655 & 396.3844 & 0 & 6303 & 435 \\
\hline Hydrological total affected & 926199.7 & 7417160 & 0 & $1.27 \mathrm{e}+08$ & 435 \\
\hline Climatological damages & 5422.067 & 49858.3 & 0 & 796000 & 435 \\
\hline Climatological death & 4.795402 & 37.9428 & 0 & 558 & 435 \\
\hline Climatological total affected & 247293.4 & 2634030 & 0 & $5.00 \mathrm{e}+07$ & 435 \\
\hline GDP per capita & 658.9108 & 518.9644 & 56.46796 & 3329.864 & 435 \\
\hline Young population & 42.69585 & 5.192969 & 17.5106 & 51.771 & 435 \\
\hline Population density & 82.26051 & 128.1624 & 1.21864 & 1071.171 & 435 \\
\hline Percentage arable area & 13.74876 & 13.40381 & 0.0431406 & 70.19283 & 435 \\
\hline Political rights & 4.88046 & 1.790775 & 1 & 7 & 435 \\
\hline Civil war & 0.2206897 & 0.4151891 & 0 & 1 & 435 \\
\hline
\end{tabular}


Table B.3: Country list

\begin{tabular}{|l|l|l|}
\hline Albania & Guinea & Papua New Guinea \\
Angola & Guinea-Bissau & Paraguay \\
Armenia & Guyana & Philippines \\
Azerbaijan & Haiti & Rwanda \\
Bangladesh & Honduras & Samoa \\
Belize & India & Senegal \\
Benin & Indonesia & Sierra Leone \\
Bhutan & Iran, Islamic Rep. & \\
Bolivia & Jordan & Solomon Islands \\
Burkina Faso & Kenya & Sri Lanka \\
Burundi & Kyrgyz Republic & Sudan \\
Cambodia & Lao PDR & Swaziland \\
Cameroon & Lesotho & Syrian Arab Republic \\
Cape Verde & Liberia & Tajikistan \\
Central African & Tanzania \\
Republic & Madagascar & Thailand \\
Chad & Malawi & Timor-Leste \\
China & Maldives & Togo \\
Comoros & Mali & Tonga \\
Congo, Rep. & Mauritania & Tunisia \\
Cote d»Ivoire & Micronesia, Fed. & \\
Ecuador & Sts. & Turkmenistan \\
Egypt, Arab Rep. & Moldova & Uganda \\
El Salvador & Mongolia & Ukraine \\
Eritrea & Morocco & Uzbekistan \\
Ethiopia & Nepal & Vanuatu \\
Gambia, The & Nicaragua & Vietnam \\
Georgia & Niger & Yemen, Rep. \\
Ghana & Nigeria & Zambia \\
Guatemala & Pakistan & Zimbabwe \\
\hline
\end{tabular}

